\title{
Depicting Contemporary Affixes To Generate Students' Linguistic And Communicative Competence
}

\author{
R. Kunjana Rahardi
}

\begin{abstract}
This brief article focuses on the various affixes and their categories in the contemporary Indonesian language. The data were collected by applying the technique of taking notes and the technique of recording. The collected data were then classified, deciphered and analyzed by applying the distributional method. The results show that there are eight prefixes in the Indonesian language, namely 'ber-, meN-, di-, ke-, per-, peng-, se-, ter-'; two types of suffixes, which are the regular suffixes of '-an, -anda, -i, -kan, -wan/wati, -in, -at', and foreign suffixes of '-isasi, -asi, -or, -ee, -e, -isme, -logi, -tas'; four infixes, which are '-el-, -em-, -er-, and -in-'; confixes of 'ke-an', 'ber-an', 'per-an', 'peng-an', and 'se-nya'; as well as two simulfixes of 'member-kan' and 'memper-kan'. The results of this study are certainly useful in the following matters: (1) to complement the traditional description of Indonesian language morphology, (2) to develop Indonesian linguistic studies. This study has limitations because it has not been able to describe the types of affixes contextually. The subsequent study is suggested to base the data taken from such authentic texts so that the results of the study can better describe the use of affixes in a more tangible context.
\end{abstract}

Keywords: Affix, morphology, linguistic perspective, contemporary Indonesian language

\section{INTRODUCTION}

In the Indonesian language, and possibly also in other languages, there is a process of forming the word which is invented from a certain basic form. This process is called affixation [1]. The basic form can be divided into two, namely the free-base form and the bound-base form.The basic form can be said to be a free-base form when it has a clear meaning even if it is not given an affix. Some sources say that such a free-base form is 'independent', meaning that it is not dependent on other linguistic elements to give it meaning. Such an independent basic form already has a syntactic category [2], although there is no grammatical process in it.For example, please note the word 'tidur' (sleep) and the word 'makan' (eat). The word 'tidur' can be referred to as a free-base form because without being given any affixes, that linguistic form already has a clear meaning. That is, the form 'tidur' is independent, not depending on any linguistic forms. In the construction of sentences, the form 'tidur' can appear, and can even be predicative. Similarly, the word

Revised Manuscript Received on November 15, 2019.

* Correspondence Author

R. Kunjana Rahardi*, Master Program of Indonesian and Literature Education, Faculty of Teachers' Training and Education, Sanata Dharma University, Yogyakarta, Indonesia. Email: kunjana.rahardi@gmail.com

(C) The Authors. Published by Blue Eyes Intelligence Engineering and Sciences Publication (BEIESP). This is an open access article under the CC BY-NC-ND license (http://creativecommons.org/licenses/by-nc-nd/4.0/) 'makan' on its own already has a clear meaning, even if there is no additional affixes in it. A correct understanding of the free-base form is essential to be presented at the beginning of this brief article.

It is different from the form 'temu' (meet) or the form 'juang' (fight), which will only have a clear meaning and becomes a free form after it joins with certain affixes that are attached to it, for example, 'bertemu' (to meet) and 'berjuang' (to fight). In the sentence, those linguistic forms that are bound-base forms cannot stand on their own. Therefore, such a bound-base form has to be given an affix in order to have a complete, clear, and independent meaning. It is correct that there are not many basic linguistic forms that are bound-base forms.Certain linguists refer to it as a 'pre-categorical' form, or commonly referred to as lexem [3]. Thus, the affixation or the process of adding the affix will be able to change the form and change the meaning - since it is common that in a language the change of the form occurs because of the need to change that meaning - both from the basic form which is bound and from the basic form which is free [4]. The linguistic form which is added to the bound-base form and free-base form is called an affix, whereas the process of changing the form as a result of the addition of the affix is called affixation [5].

This brief article will focus on the various affixes and their categorization - not the affixation - that are found in the contemporary Indonesian language which is the evidence of the development of the field of morphological studies as one of the branches in linguistics. Thus, the purpose of this study is to describe the various affixes and their categorization which are contained in the morphology of the contemporary Indonesian language, not on the affixation process.The results of this study are certainly useful in the following matters: (1) to complement the traditional description of Indonesian language morphology which in general has been conducted by Indonesian scholars in the past; (2) to develop Indonesian linguistic studies which are generally abandoned by linguists since many of them have turned to the extralinguistics fields [6].

\section{RESEARCH METHODOLOGY}

The data source of this linguistic study on affixes in the development of contemporary Indonesian language morphology is the ordinary language spoken by the native speakers of Indonesian language. Thus, the data of this linguistic study are in the form of linguistic entities [7], in particular the words that contain affixes, which are derived from the speeches of the native speakers of the language.

\section{Published By:}

Blue Eyes Intelligence Engineering and $\mathrm{Hu}$

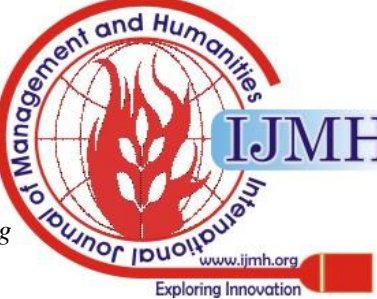


It thus follows the view of Sudaryanto who asserts that data are the object of the study that come along with the context [8].

Considering that the object of this study is the affixes along with the categorization, then the data of this study are the words which contain affixes with all kinds of their types and variations. In addition, the data are also creatively-innovatively derived from the researcher's own linguistic intuition given that the researcher is a native speaker of Indonesian language [9]. Native speakers of Indonesian language whose lingual intuition can be derived from are the speakers who are confirmed to still have a lingual distance which is worthy of innovatively and creatively generated in the process of collecting the data. This is in line with what is presented by Sudaryanto, and which is followed by Rahardi and Setyaningsih [7].

The data of this study were collected by applying the technique of taking notes and the technique of recording. Both of these data collection techniques are complementary and have their own advantages. Furthermore, the collected data were classified and deciphered before being analyzed by applying the distributional method, both with the immediate constituent analysis technique and the ultimate constituent analysis technique. The results of the data analysis were further described in detail as well as interpreted by linking relevant theories and the in-depth interpretation results from the researcher himself as a linguist in order for the morphological facts and perspectives in the development of the contemporary Indonesian language to be described in detail [10].

\section{RESULTS AND FINDINGS}

The prefix is an affix which is placed directly in front of the basic form, so the two linguistic forms are closely intertwined and united together into an invented word [11]. It should also be noted, however, that the basic form attached to the prefix can be a basic word, and can also be an invented word. That is, the prefix that attaches on the basic word will form the invented word, while the invented word that is attached to the prefix will be a new bigger invented word. For example, the basic word 'tidur' (sleep) which when added with the prefix 'ter-' will change into an invented word or the affixed word 'tertidur' (asleep).

Similarly, the basic form which is the invented word 'kinerja' (performance), whose basic word is 'kerja' (work) and obtains the infix '-in-', will be able to change into a new invented word 'berkinerja' (performing) after the first invented word is given the prefix 'ber- '. Therefore, it is obvious that prefix can attach to the basic form which is the basic word, and can also attach to the invented word.

From a number of literatures, it is found that in Indonesian language - at least up to present time - there are eight prefixes [12]. Consecutively, the prefixes in Indonesian language are 'ber-, meN-, di-, ke-, per-, peng-, se-, ter-' as in the words 'berjudi' (gambling), 'mengatur' (organizing), 'dicium' (kissed), 'kedua' (second), 'persegi' (square), 'penggali' (digger), 'setempat' (local), 'tertembak' (hit).

Prefix 'ber-' in Indonesian language has several variations. In the previous section it has been explained that 'ber-' is a morpheme, which is a bound morpheme, then the variation of 'ber-' morpheme into 'bel-', 'be-', and 'ber-' itself, can be referred to as allomorph [13]. Thus, it can be said that 'ber-' morpheme has three allomorphs as shown above. However, in order to facilitate understanding, the terms morphemes and allomorphs will not be used in this section, simply for the purpose of facilitating understanding and avoiding ambiguity. The main focus in this section does not discuss morphemes and allomorphs, but about prefixes and the variations of the prefixes as their realization.

The following are the list of some examples of the realization of the prefix 'ber-' that changes into 'be-' in the Indonesian language: 'bekerja' (work), 'beternak' (breed), 'beterpa' (pursue), 'berotan' (with rattan), 'becermin' (reflect), 'beserta' (together with), 'bepergian' (traveling), 'berenang' (swim), 'berendam' (soak), 'berupa' (in the form of), 'beransel' (with a backpack), 'berolak' (turn), 'beragi' (with yeast), 'beramai' (match), 'berantai' (with a chain), 'berambu' (with signs), 'berambut' (haired), 'berenda' (lacy). The realization of prefix 'ber-' to 'bel-' is limited to the words 'belajar' (learn), 'belujur' (learn). Variations of prefix 'ber-' into 'ber-' itself is indeed most commonly found in the Indonesian language.

As the materials to search for further data on the words containing the 'ber-' realization in the form of the 'ber-' variation, the following list should be noted: 'berpikir' (think), 'berjudi' (gamble), 'bertanam' (plant), 'bersantap' (eat), 'bernyanyi' (sing), 'bersawah' (paddy field), 'berdagang' (trade), 'berabang' (having an older brother), 'beradik' (having a younger sibling), 'bertuan' (having a master), 'beribu' (having a mother), 'bertelur' (lay egg), 'beranak' (having children), 'berbunyi' (make sound), 'berhasil' (succeed), 'beruntung' (lucky), 'berdisiplin' (having a discipline), 'bertakwa' (faithful), 'bersemangat' (excited), 'berdukacita' (mourning), 'bersukacita' (rejoice), 'berpesta' (partying), 'bersitegang' (arguing), 'bertulis' (inscribed), 'berjawab' (answering), 'berhias' (titivating), 'bercukur' (shaving), 'bersimbah' (wasted), 'berguru' (studying), 'berdamar' (camouflage), 'bersatu' (united), 'bersepatu' (wearing shoes), 'berbaju' (dressed), 'bercelana' (wearing pants), 'bernama' (named), 'beristri' (having a wife), 'bersuami' (having a husband), 'berkereta' (using train), 'berkedai' (having a shop), 'bermain' (play), 'bersedih' (grieving), 'bergembira' (rejoice), 'bercokol' (staying), 'beranjak' (getting up), 'bergeming' (moving), 'berantuk' (stumble), 'bersama' (together), 'bersua' (meet), 'berjumpa' (meet), 'bermobil' (having a car), 'bertaksi' (using a taxi).

The general meaning of the prefix 'ber-' with its various realization as indicated previousy is unfinished, or is ongoing (atelisic) [14]. For example, the word 'belajar' (learn) which contains a variation of 'bel-' from the prefix 'ber-', then it is clear that the 'ajar' (teach) activity is in progress and not yet finished. Similarly, if we take the word 'bersitegang' (have an argument), then it is certain that the activity of 'sitegang' (argue), which also means 'seteru' (fight) is in progress. For certain, Kridalaksana's conclusion needs to be given much deeper attention from the lecturers, researchers, students, and most of all other linguists. They need to justify that the general meaning - which in the researcher's understanding is the basic meaning - is indeed 'unfinished' or 'ongoing'.
Published By:

Blue Eyes Intelligence Engineering \& Sciences Publication

(C) Copyright: All rights reserved. 
It is suggested that the search for the basic meaning is done more carefully, by always questioning the 'meaning which is considered basic' in the next stage of meaning. Until the question of the inherent meaning can no longer be done, it is almost certain to conclude that it is the basic meaning of certain prefixes [15], in this case is the prefix 'ber-' . It also seems worthy to note that in fact the forms with the 'ber' prefix - although not all of them - are in many ways correlated with the prefix 'ke-' in non-standard variations. Therefore, in informal conversation, people often say, 'ketemu' (meet) while the intention is 'bertemu' (meet). My close friend always greets by saying 'Sampai ketemu ya!' (See you!) to his friends.

Such linguistic form is for certain acceptable only within the oral context, and even in the informal and non-standard context [4]. If we look more closely at the prefix 'ber-', there are other forms of 'ber-' that have not been described previously, such as the form 'berfoya-foya' (spree), 'bersantai-santai' (relaxing), 'berjingkat-jingkat' (tip toe), 'berjuntai-juntai' (dangling), 'beramai-ramai' (crowding), 'bersorak-sorai' (cheering). Well, it turns out that the prefix 'ber-' in realization of the variation of 'ber-' itself is also present in a form which is a reduplication or iteration as shown previously.

Some sources call the prefix as 'meng-, not 'meN- ', but consistently, in this article the 'meN-' form is used. Indeed, in certain sources the form 'meng-' is used, but in the researcher's opinion, the 'meng-' form itself is merely a realization of the variation of 'meN-' in the initial phoneme condition of a certain basic form [16].

In the realization of the variations, the 'meN-' form has several forms which are commonly referred to as allomorphs within the framework of the morpheme discussion The allomorphs of the 'meN-' form are as follows: 'me-', 'men-', 'meny-,' and 'menge-', and all of that occur after the ' $N$ ' on the 'meN-' undergoes the morphophonemic process after joining a particular phoneme that begins the basic form it joins. For example, the 'meN-' prefix will be realized into 'menge-' after encountering a basic form of one syllable such as 'bom' (bomb) or 'tik' (type). And so then the form 'mengebom' (bombing) and 'mengetik' (typing) emerged in the Indonesian language. However, the 'meN-' prefix will be realized into 'meny-' because the initial phoneme of the basic form it joins is /s/ as in 'sapu' (broom) or 'simpan' (save). Therefore, in the Indonesian language there is a form of 'menyapu' (sweep) and 'menyimpan' (save).

Thus, to facilitate the studying of each of the variation realizations of 'meN-', they will be explained one by one in the following section.

(1) ' $M e N-$ ' will change into 'meng-' if the basic form it joins begins with the following phonemes: / $a, e, o, u, i, e, g, k$, $k h, x, h /$. Therefore, just to facilitate understanding, it can also be said that the 'menge-' form will be present in ten possible initial phonemes of the basic form, which are five vowels and five consonants. For example, consider the following words: 'menganalisis' (analyzing), 'mengatur' (organizing), 'mengekor' (following), 'mengentut' (fussing), 'mengolah' (processing), 'mengobati' (treating), 'mengukur' (measuring), 'mengubah' (changing), 'mengendap' (settling), 'mengempas' (tossing), 'menginjak' (stepping), 'mengimbau' (appealing), 'menggergaji' (sawing), 'menggaji' (hiring), 'mengemas' (packing), 'mengumpulkan' (gathering), 'mengkhawatirkan' (worrying), 'mengkhazanahkan' (realizing), 'mengharapkan' (expecting), 'menghasilkan' (producing). It should also be noted that the basic form that begins with the phoneme ' $x$ ' is very limited in the Indonesian language. The latest KBBI which was released in 2008 only recorded 48 entries for the words that start with ' $x$ '. Thus, it is only natural that it is very difficult to get an example of the basic form beginning with ' $x$ ' in the Indonesian language, and therefore it is very difficult to find examples of the realization of the variation of 'meN -' into 'menge-' with such very limited number of basic forms. It should also be noted that when the basic form has an initial phoneme of $/ \mathrm{k} /$, as in the word 'kulum' (suck), it will be ommitted. However, it is not always the case that such $/ k$ is ommitted because it is often necessary to distinguish the meaning of a particular word. In the form 'mengaji' (studying Islam religion) and 'mengkaji' (discussing in-depth), for example, it is obvious that the basic form is 'kaji' (study), but in one form the / $k$ / is ommitted while in the other one it is not ommitted. Those two words also do not have the same meaning, because one means 'memikirkan dalam-dalam' (to think deeply) while the other one means 'belajar agama Islam dengan guru agama Islam' (to study Islam religion with an Islam religion teacher).

(2) ' $M e N-$ ' will change into ' $m e-$ ' if the basic form it joins begins with the following phonemes: /l, $r, w, y, m, n, n g$, $n y /$. In order to facilitate understanding, it can also be said that the realization of the variation of ' $\mathrm{mem}$-' to ' $\mathrm{meN}$ occurs in eight possible initial phonemes of the basic form. For example, consider the following words: 'melempar' (throwing), 'meluruskan' (straightening), 'merampas' (seizing), 'merampok' (robbing), 'mewarisi' (inheriting), 'mewartakan' (proclaiming), 'meyakinkan' (convincing), 'meyatimkan' (to make someone an orphan), 'memalukan' (embarrassing), 'mematangkan' (ripen), 'meninabobokan' (lulling), 'menamakan' (naming), 'menganga' (gaping), 'mengamen' (begging for money by singing), 'menyanyi' (singing). It should be noted that the words beginning with 'ny-' are very limited in Indonesian language. Unlike in Javanese language, where 'ny-' is commonly used to mark active verbs in the language, as in 'nyethol' (pinch lightly) and 'nyamul' (touch lightly sexually). For certain, such linguistic form cannot be immediately added an Indonesian language prefix 'meN-' so that it becomes 'menyethol' and 'menyamul'. These latter linguistic forms appear only in informal conversation, and are usually used by a Javanese person who tends to be less fluent in speaking Indonesian language, but wants to speak Indonesian language. As a result, some forms of Javanese language interference emerge in their use of Indonesian language.

(3) ' $M e N-$ ' will change into 'men-' if the basic form it joins begins with the following phonemes: / $d, t, s y, z /$. Therefore, the emergence of the form 'men-' is only possible in four possible positions, as can be seen on the words 'mendepak' (kicking), 'mendamprat' (cursing), 'menambak' (embanking), 'menembus' (penetrating), 'mensyaratkan' (requiring), 'mensyiarkan' (broadcasting), 'menzakatkan' (giving charity), 'menzinakan’ (fornicating).

Published By:

Blue Eyes Intelligence Engineering \& Sciences Publication

(C) Copyright: All rights reserved. 
Indonesian language also does not have too many words with the initial phonemes of $/ s y /$ and $/ z /$, so that the realization of variation of 'meN-' into 'men-' is also relatively difficult to find. It should be noted that the early phonemes of $/ t /$ in its usage are often ommitted, but are also often found to be not ommitted. The word 'menerjemahkan' (translate) and 'menterjemahkan' are commonly encountered in our daily lives. However, for the sake of consistency, in accordance with the linguistic terms above, we have to familiarize ourselves to use the ommitted form. Therefore, the preference is the word 'menerjemahkan', not the word 'menterjemahkan'. Similarly, we have to familiarize ourselves to use the form 'menertawakan' (laugh at), not the form 'mentertawakan'.

(4) 'MeN-' will change into 'mem-' in four alternative positions, which are if the basic form it joins begins with the following phonemes: $/ b, f, p, v /$ as can be seen on the following words: 'membina' (nurturing), 'membawa' (carrying), 'memfitnah' (slandering), 'memfatwakan' (fussing), 'memarkir' (parking), 'memikirkan' (thinking), 'memvariasikan' (varying), 'memvaginapalsukan' (faking the vagina). There are very few words which have the initial phoneme of ' $v$ ' in Indonesian language. It is therefore very difficult to find examples of words that contain the realization of variations of 'meN -' into 'mem-' in Indonesian language. It should be noted that the phoneme $/ p /$ on the basic form will essentially be ommitted when it joins the 'meN-', but when the basic form has the prefix 'pe-' or 'per-', the ommission does not occur. The forms 'memercayai' (trusting) and 'memedulikan' (caring) are the correct form, but the forms 'memeringati' (celebrating) and 'memeranakkan' (breeding) are the incorrect forms. One important note needs to be made on the form 'memperhatikan' (paying attention), which used the form 'memerhatikan' in the KBBI before the 4th edition in 2008 because at that time, it was considered that its basic form was 'perhati' (observe) and 'per-' on the basic form was not a prefix so that when it obtains 'meN-', the /p/ in 'perhati' is ommitted so it becomes 'memerhatikan'. However, what is considered to be correct now is 'memperhatikan' because the / $p$ / in 'perhati' is a prefix, so that it cannot be ommitted as what has been explained by the rule presented previously.

(5) ' $M e N-$ ' will change into 'meny-' if the basic form it joins begins with the following phonemes: /s, $c, j$ / as seen in the words 'menyapu' (sweeping), 'menyalib' (crucifying), 'menycuci' (washing), 'menyecemooh' (mocking), 'menyjanjikan' (promising), 'menyjatuhkan' (taking down). It should be noted that the forms 'menycuci, menyecemooh, menyjanjikan, menyjatuhkan' never exist in the written Indonesian language, although they exist in the pronunciation of the words. For the sake of orthographic, as well as the ease in the way of pronouncing as has been recorded by Arifin (2007:20), therefore, the ' $y$ ' on 'meny-' is ommitted, so that what emerges are the forms of 'mencuci, mencemooh, menjanjikan, menjatuhkan'.

(6) 'MeN-' will change into 'menge-' if the basic form it joins with is a word with one syllable as has been discussed in the previous section. The one-syllable-word are for example: 'bom' (bomb), 'tik' (type), 'las' (weld), 'rem' (brake), 'cat' (paint), 'bor' (drill). In this case, together with those basic forms, 'meN-' will realize into 'mengeso that those words become 'mengebom' (bombing), 'mengetik' (typing), 'mengelas' (welding), 'mengerem' (braking), 'mengecat' (painting), 'mengebor' (drilling). By looking at this latter fact, it has to be emphasized that as a revision of various opinions in a number of linguistic and/or Indonesian language grammar books, that the determiner of the realization of the variation of the 'meN-' prefix is not always the initial phoneme of its basic form because there are also changes whose determiner is the number of syllables of the basic form words.

There is not much to say about the prefix 'di-' in Indonesian language, except that the 'di-' prefix serves as a passive verbal prefix. The prefix that forms the passive verb is correlated with the 'meN-' prefix as described earlier. So, the form 'dipukul' (being hit) has to be correlated with the form 'memukul' (to hit), the form 'dicium' (to be kissed) has to be correlated with the form 'mencium' (to kiss). A very important thing that can also be noted with respect to the 'di-' prefix is that ' $\mathrm{di}^{-}$' as a prefix is different from ' $\mathrm{di-}$ ' as a preposition. For the latter, the writing must not be connected, but has to be separated. Thus, the forms 'di meja' (on the table) and 'di kampus' (at the campus) are the correct ones. Therefore, if ' $\mathrm{di}$-' is followed by a word that indicates a place, the writing should be separated and cannot be connected.

Regarding the prefix 'ter-' in Indonesian language, there are three important things to note as the realization of the variation. Firstly, that 'ter-' will change into 'te-' when combined with the basic form that begins with the phoneme $/ r /$, as in the forms 'terebut' (grabbed) and 'terangsang' (aroused). In Indonesian language, it is not possible to write the form 'terrangsang' and 'terrebut' by repeating the $/ r /$ phoneme. Thus, the solution, the $/ r /$ on 'ter-' will disappear so that there is only one $/ r$ / in its orthographic form. Secondly, when the first syllable of the basic form associates with the 'ter-' prefix that ends with 'er' as in the words 'percaya' (believe) and 'cermin' (mirror), then the $/ r$ in the 'ter-' prefix will disappear.

Therefore, the following linguistic forms have to be considered correct: 'tepercaya' (trusted), 'tecermin' (reflected), 'tepercik' (splashed), 'tepergok' (caught red-handed), 'teperdaya' (fooled). The forms that exist earlier, which are 'terpercaya, tercermin, terpercik, terpergok, terperdaya' until this present time are still competitive forms indeed, but it is strongly recommended to use the forms that are suitable with the morphophonemic rule as mentioned earlier.

It should be noted that in relation to this 'ter-' prefix, there is also the realization of variations of 'ter-' into 'tel-' as in the words 'terlanjur' (already) and 'telanjur' eventhough it has very limited frequencies of occurrence. In addition to the forms of /ter-/ prefix as mentioned earlier, the prefix 'ter-' realizes as 'ter-' as in the following words: 'terluka' (wounded), 'terbawa' (carried), 'tertawa' (laugh), 'terpana' (stunned), 'tersiksa' (tortured), 'terkesima' (amazed), 'terganggu' (annoyed). It should also be noted that the prefix 'ter-' has an equivalent to 'ke-' in a non-standard or informal context in regional dimension, for example on the words 'ketawa' (laugh) and 'ketabrak' (struck) as well as 'kepukul' (beaten).

Published By:

Blue Eyes Intelligence Engineering

\& Sciences Publication

(C) Copyright: All rights reserved. 
There will never be a change of form as the realization of prefix variation of ' $k e-$ ' in Indonesian language, when the ' $k e-'$ prefix joins with any basic forms. The forms 'kedua' (second) and 'ketua' (leader), for example, are a combination of the 'ke-' prefix and the basic form of 'dua' (two) and the basic form of 'tua' (old) which do not experience any changes at all. That means, in terms of its morphophonemic process, there are no very important things that need to be observed and should be noted related to this 'ke-' prefix.

As has been noted in the explanation of 'ter-' prefix earlier, the 'ke-' prefix has a very close association with the 'ter-' prefix, especially in the use of informal and non-standard forms. The form 'ketawa' (laugh) correlates with 'tertawa', the form 'kecium' (smelled) correlates with 'tercium', and the form 'keinjak' (stepped) correlates with 'terinjak'. From the form 'ketawa' and the form 'kecium', it can be seen that even though it is not formal, those forms show the 'ke-' prefix as the verb.

As from the forms 'kedua' and 'ketua', it is known that the 'ke-' prefix serves as the noun. It may also be said that the first 'ke-' is a verbal prefix, because the prefix is in charge of forming a verb, even if the context is not standard. As for the latter, the 'ke-' prefix serves as a 'nominal' prefix because it is in charge of forming nouns from the adjectives.

In earlier sections, when the prefix 'ber-' is explained, we understand that 'ber-' has three types of variation realization, which are 'ber-', 'ber-', and 'be-' [17]. The same thing happens to the prefix 'per-', which also has three types of variation realization, which are 'pe-', 'per-', and 'pel', as in the words 'peserta' (participant) and 'pedagang' (seller) for the example of 'per-' that becomes 'pe-', 'perbesar' (zoom in) and 'perkecil' (zoom out) for the examples of variation realization of 'per-' into 'per-' itself, and 'pelajar' (student) for the example of variation realization of 'per-' into 'pel'.

Normally, the prefix 'per-' that realizes into 'per-' can be used to form verbs, whereas the realization of 'pel-' and 'pe-" usually form nouns. The form 'perindah' (beautify) for example, is obviously a verb because the meaning refers to a certain action, which is the action to 'make beautiful'. The form 'pelajar' (student) is a noun, which is formed from the basic form that serves as a verb. Therefore, the prefix 'per-' that changes into 'pel-' in the word 'pelajar' functions as a noun prefix.

It has been explained earlier that the prefix ' $m e N-$ ' can be realized into variations of 'meng', 'meny-', 'me-', 'men-', each with different original phoneme condition from the basic forms that follow them. The same with the morphophonemic process that occurs in the prefix ' $m e N-$ ' as described earlier, in the prefix ' $p e N-$ ', the same condition for the phoneme / $N /$ change apllies.

In brief, it can be stated that the prefix ' $p e N-$ ' will change into 'peng-' if the basic forms start with the following phonemes /a, $i, u, e, o, g, k, h, k h, x /$ as in the words: 'pengambil' (taker), 'pengintai' (scout), 'penggulai' (a person who makes curry), 'penggarong' (robber), 'penguras' (drainer), 'pengemas' (packager), 'penghapus' (eraser), 'penghambat' (inhibitor), 'pengalayakan' (entrusted). In fact, the basic forms that start with the phoneme $/ x /$ are very limited and very difficult to find.

In general, it can be said that the prefix " $p e N-$ " functions to change a form which is not a noun into the noun form. Therefore, it is common to say that 'peN-' is a noun prefix. The form 'pengawal' (bodyguard) is obviously a noun, that linguistic form is formed from the entity which is not a noun, that is 'kawal' (guard). Similarly, the form 'penulis' (writer), is previously a noun with the basic form of 'tulis' (write) which is originally a verb. After it obtains the prefix 'peN-' or obtains the noun prefix 'peN-', it changes into 'penulis'.

The prefix 'se-" has two manifestation, the first is to form adverbs, as in the words 'semaunya' (arbitrarily) or 'sekenanya' (randomly), and the second is as clitics. The form 'sekamar' (in one room) certainly has a different meaning from 'semestinya' (supposed to be) or 'semaunya' (arbitrarily), because the prefix 'se-' in the form 'sekamar' (in one room) or 'serumah' (in one house) refers to the entity of 'keesaan' (unity). That means to have one dimension or having the nature of only one. For example, the form 'serumah' means in one house.

Similarly, in the form 'sekamar' the meaning is in one room. However, in the form 'batu serumah', the prefix 'se-' has a meaning of 'the same with' or 'similar with'. Nevertheless, as mentioned by Arifin, the linguistic form has a basic meaning of 'one' or 'united' as well [18]. It should also be noted that the prefix 'se-" that serves to form adverbs, can also join with the reduplication form, for example in the forms 'secepat-cepatnya' (as fast as possible) or 'selambat-lambatnya' (at the latest); there is also an adverb form which does not contain repetition as mentioned earlier.

Suffix is firmly attached to the basic form of a word, not on the front position but on the final position. Thus, the fact is in contrast to the prefix that is firmly attached to the front position of the basic form. In the Indonesian language, there are some suffixes, for example '-an', '-anda', '-i', '-kan', '-wan/wati', '-in', '-at'. Those suffixes are commonly considered as the non foreign suffix. The suffixes that are categorized as foreign suffixes are '-isasi', '-asi', '-or', '-ee', '-e', '-isme', '-logi', '-tas'. The forms of each of those suffixes are discussed in the following section one by one.

There are at least four manifestation of the suffix ' $-a n$ ' in the Indonesian language, which are '-an' that forms a noun, '-an' that forms a verb, and ' $-a n$ ' that forms an adjective. The first type is called a noun suffix, the second is called a verb suffix, and the third is called an adjective suffix. In general, the forms with the suffix ' $-a n$ ' are related with the verbs that begin with ' $m e N-$ ', and have a meaning of 'result' or 'consequence'. Thus, for example the form 'asinan' (pickles), has to be the consequence or the result of the activity of 'to make salty'.

Similarly, in the form 'taruhan' (bet), the meaning has to be related to the verb 'menaruh' (to put), or can also be said as a result of the activity mentioned in the verb 'menaruh'. The noun forms of the suffix ' $-a n$ ' can be mentioned as follows: 'tulisan' (writing), 'kritikan' (criticism), 'adonan' (dough), 'amukan' (rage), 'asuhan' (care). Whereas the verb forms of the suffix '-an' can be found on the words such as 'tabrakan' (collision) or 'langganan' (subscribe).

In general, the forms as mentioned earlier are not formal, and are only often present in the variety of conversation which are the partial form of the more complete verb forms. The form 'tabrakan' as in the sentence 'Mereka berdua tabrakan di gang lantai dua bangunan itu.' (They both collided in the second floor alley of that building.), actually has the complete form of 'bertabrakan'.

Published By:

Blue Eyes Intelligence Engineering \& Sciences Publication

(C) Copyright: All rights reserved. 
The same thing occurs in the form 'langganan' in the sentence 'Saya segera langganan surat kabar baru itu.' (I immediately subscribe to the new newspaper.), the complete form is 'berlangganan'.

In the informal type of Indonesian language, such linguistic forms are certainly easy to find. In order for you to be able to understand such linguistic forms deeper, please record all those linguistics forms, and observe whether each of the linguistic forms has other meaning. In addition to having the dimension of nouns and verbs as discussed earlier, the suffix ' $-a n$ ' also has the dimension of adjectives. That means, besides the verb suffix and the noun suffix, there is also the adjective suffix in the Indonesian language, even though it is informal. The forms like 'kecilan' (smaller) or 'gedean' (bigger) are present in the ordinary use of Indonesian language, and those forms serve as adjectives.

In the form 'kampungan' (countrified) or in the form 'banyakan' (most) as well, it is obvious that the suffix ' $-a n$ ' serves to form adjectives. The fourth type is the suffix ' $-a n$ ' to form numbers. The forms like 'puluhan' (dozens) and 'ratusan' (hundreds) are obviously numbers in Indonesian language, in which each of them is formed from the number 'puluh' (dozen) and 'ratus' (hundred), which become the number of 'puluhan' and 'ratusan'. The meaning refers to the meaning dimension of 'group' or 'unit'.

In the embodiment, the suffix '-anda' often becomes ' $-n d a$ ', and is commonly used in a kinship terms. Thus, in the Indonesian language there are forms with the suffix ' $-a n d a$ ' or ' $-n d a$ ' as in the words 'kakanda' (brother) and 'mbakyunda' (sister). Also, in the forms 'ayahnda' (father) or 'ayanda', 'anaknda' (child) or 'ananda'. The general purpose of the use of linguistic forms with the suffix '-anda' or ' $-n d a$ ' is to give respect or appreciation to someone. In certain references, the suffix '-anda' or ' $-n d a$ ' can be called as 'honorific sufix' or a suffix that functions as a marker of respect.

In Indonesian language there are two types of suffix ' $-i$ ', namely suffix ' $-i$ ' that forms a verb, and suffix ' $-i$ ' that forms an adjective. Therefore, it can be asserted that the suffix ' $-i$ ' has two manifestations, which is as a verbal suffix and as an adjectival suffix. The suffix that forms verbs are for example, 'hadapi' (to face), 'tanami' (to plant), 'duduki' (to sit on), 'kuliti' (to skin). Meanwhile, the suffix that forms adjectives are for example, 'badani' (physical), 'ragawi' (physical), 'duniawi' (worldly), 'gerejawi' (ecclesiastical), 'manusiawi' (humane). Certain sources mention that the suffix ' $-i$ ' can be manifested into ' $-w i$ ', and can also be manifested into '-iah' or '-wiah'. The suffix '- $i$ ' and the suffix ' $-w i$ ' are considered as the suffixes that are masculine, whereas the suffixes '-iah' and '-wiah' are considered as the suffixes that are feminine.

According to the researcher's observation, there is only one function manifestation of the suffix '-kan' in the Indonesian language, which is as a suffix that forms a verb. Therefore, we can say that the suffix '-kan' functions as a verbal suffix, for example in the word 'pukul' (hit) becomes 'pukulkan' (to hit), the word 'tidur' (sleep) becomes 'tidurkan' (to sleep), and the word 'dengar' (listen) becomes 'dengarkan' (to listen). If we pay close attention, all the linguistic forms which end in '-kan' as mentioned earlier are verbs. Therefore, it can be asserted that the suffix '-kan' really functions as a suffix that forms a verb.

In the discussion of morphemes as explained in the previous section, it has been asserted that the linguistic forms such as '-wan' or '-wati' or '-man' are the bound morphemes.
As a morpheme, it is obvious that such linguistic forms are bound morphemes. In the discussion of affix, such linguistic forms can be referred to as suffix that forms a noun, for example the adjective 'sukarela' (voluntary) can be changed into a noun 'sukarelawan' (volunteer), the form 'harta' (wealth) can be changed into 'hartawan' (tycoon), the form 'warta' (news) can be changed into 'wartawan' (journalist), the form 'derma' (charity) can be changed into 'dermawan' (generous), the form 'drama' (drama) can be changed into 'dramawan' (performer).

Certain literature mentions that the form '-in' is actually absorbed from Arabic language, and the suffix ' $-i n$ ' is closely related with sex, which is male in general. Thus, the Indonesian word of 'hadirin' has a meaning of 'a man who is present', the word 'muslimin' has a meaning of 'a moslem man'. We have to admit that in Indonesian language, the suffix ' $-i n$ ' is categorized as not productive, so there are only very limited numbers of words with the suffix ' $-i n$ '.

The suffix '-at' as in the words 'muslimat' and 'mukminat' as well as 'hadirat' is sligthly different from the suffix '-in' as mentioned earlier which has the tendency to have the meaning of having masculine quality or manly. The meaning of the form 'muslimat' is 'a moslem woman', 'hadirat' is 'a present woman', whereas 'mukminat' means 'a believing woman'.

However, it should also be noted that in relation with the suffix '-at', that not all words that end in '-at' refer to a woman. The word 'akhirat' and the word 'rektorat' as well as the word 'dekanat' are obviously have no relation with the matter of female sex. The meaning of 'akhirat' is 'the afterlife', which is the life after this life in the mortal world. The meaning of the word 'dekanat' is a place that takes care of the duties and work of a dean in a university.

Similarly, the word 'rektorat' has a meaning of a place that takes care of the duties and work of a rector in a university. Let us not forget that within the scope of government departments, there are many parts of the department which is lead by a director, which is then commonly referred to as a 'direktorat' (directorate). Also for the word 'sekretariat' (secretariat), which does not seem to be a strange word in the ears of many people, which also has a meaning that is totally unrelated to the sex matter mentioned earlier.

In Indonesian language, the suffix '-isasi' generally refers to the meaning of 'process', as in the word: 'nominasi' (nomination) which also means 'process', which is the process of nominating candidates. The same thing applies for the form '-isasi' on the word 'legalisasi' (legalization) whose meaning is 'the process of legalizing' or 'the process to make legal'. In addition to the form '-isasi', in Indonesian language there is also the form of '-asi', as in the word 'spesifikasi' (specification) and the word 'klasifikasi' (classification). Both the forms '-isasi' and '-asi', come from the English forms of '-ation' or '-ion', as in the word 'nominasi' which comes from the English word 'nomination'.

The form 'legalisasi' is also present in the English form 'legalization'. The form 'spesifikasi' comes from the English word 'specification', whereas 'klasifikasi' comes from the English word 'classification'.

Published By: Blue Eyes Intelligence Engineering \& Sciences Publication 
The forms '-isasi' and '-asi' are included into the productive suffix in Indonesian language, so there are quite many words with that suffix in the ordinary Indonesian language.

However, it should also be noted that in the development of the use of contemporary Indonesian language nowadays, there are many analogies that are not completely correct in relation with the use of this type of suffix. The forms like 'turinisasi' and 'lampunisasi', even though they contain the meaning of 'process', which is the process of 'touring' and the process of 'installing lamps', cannot be considered as correct forms. The reason is that the suffix '-isasi' in that linguistic form does not come from the foreign suffix of '-ion' or '-ation', but merely an analogy from the forms that use '-isasi' or '-asi' as mentioned earlier.

The linguistic form such as 'nominator', 'nominee' dan 'nomine', are very often used in various media. The forms with the suffix '-or', as in the word 'nominator' has to be understood as 'a person who nominates'. The reason is, the suffix '-or' has a meaning of 'performer' or 'a person who $m e N-$ '. Therefore, the word 'nominator' means 'a person who nominates'. Thus, the form like 'fasilitator' which is taken from an English word 'facilitator', also has the meaning of 'a person who facilitates' or 'a person who provides facilities'. The same thing applies for the word 'kreditor' (creditor) or 'debitor' (debtor), as well as on the words 'aktor' (actor) and 'konselor' (counselor).

As for the word 'nominee', the word with the suffix '-ee', has the meaning of 'a person who is nominated'. Thus, it is exactly the same with the word 'trainee' which also means 'a person who is undergoing the training'. In English there is also the word 'employee', which is a person who is being employed. Therefore, the meaning that is contained in the suffix '-ee' as shown earlier is 'a person who is subject to an action'.

Different from the suffix '-or' which means 'a person who does an action', the passive meaning is contained in the words with the suffix ' $-e e$ ' as shown earlier. In the Indonesian language, the form ' $-e e$ ' as a suffix is generally manifested into ' $-e$ ', as what also contained in the word 'nomine' (nominee) which also means 'a person who is nominated'.

The suffix '-isme' comes from the form '-ism' in foreign language, as in the word 'communism' which in the Indonesian language becomes 'komunisme'. The foreign form 'socialism' will change into 'sosialisme', whereas the form 'fundamentalism' is present as 'fundamentalisme' in the Indonesian language. In general, the linguistic form that ends in '-isme' refers to the meaning of 'aliran' (sect) or 'paham' (fathom). Thus, the form 'strukturalisme' means 'structural sect', as well as the word 'pragmatisme' can be understood as 'pragmatic sect'. However, on the words 'fundamentalisme' and 'komunisme', the meaning of 'fathom' is stronger than the meaning of 'sect'.

It is undeniable that the suffix '-is' is close in meaning with the form of '-ism' as shown earlier. The meaning contained by the suffix '-is' is 'the person concerned or the person who is related to'. Thus, the form 'fundamentalis' (fundamentalist) can be generally understood as 'a person who is related to fundamentalism'.

The suffix '-logi' can be categorized as foreign because it comes from the English form of '-logy'. In accordance with the rules of absorption in the Indonesian language, ' $-y$ ' in the final position as in the form '-logy' will be absorbed into ' $-i$ '. Therefore, we can easily find the forms like 'morfologi' (morphology), 'fonologi’ (phonology), 'kronologi' (chronology), and many others.

This suffix is also related to '-is' and '-isme' which in the previous section have been said to be a noun-forming suffix. The '-istis' form in the Indonesian language serves as an adjective. Thus, we will easily get the form of 'optimistis' (optimistic) as an adjective, whereas the noun is 'optimis' (optimist). Similarly, in the adjective 'pesimistis' (pessimistic), the noun form is 'pesimis' (pessimist). In everyday use, people often misinterpret the linguistic forms. That means, the actual form which is a noun is regarded as an adjective, and otherwise the form which is an adjective is regarded as a noun.

In the Indonesian language, there is an affix that is in the form of infix, although in a very limited number. There are four infixes in the Indonesian language, they are '-el-', '-em-', '-er-', and '-in-', as seen in the following examples: 'telunjuk' (fore finger), 'gemerincing' (clatter), 'geretak' (snarl), and 'kinerja' (performance). It tends to be said that in Indonesian language, the infix is not productive enough. That means, as a tool to form a new word, the affix in the form of infix is not reliable enough in the Indonesian language.

There are five types of confix in Indonesian language, namely (1) 'ke-an' confix, (2) 'ber-an' confix, (3) 'per-an' confix, (4) 'peng-an' confix, and (5) 'se-nya' confix. Confixes are also called split affixes because their presence is always split between one basic form. In addition to being referred to as a split affix, confix is also referred to as a single affix. The reason is, the two elements of confix at the beginning and at the end must present together at once, not gradually as happens in the case of simulfix.

These are the examples of words that contain those confixes: 'keadilan' (justice), 'berlarian' (running around), 'persetujuan' (agreement), 'pengadilan' (court), and 'sesudahnya' (afterward). There are many words in the Indonesian language that are formed by replacing the five confixes. Thus, it can be said that confix in Indonesian language is productive. That means, the formation of words in the Indonesian language can be done easily by replacing the confix.

There are two types of simulfix in Indonesian language, namely (1) 'member-kan' simulfix and (2) 'memper-kan' simulfix. Among others, the words that contain those simulfixes are: 'memberlakukan' (enacting) and 'memperlakukan' (treating). The words 'memberlakukan' and 'memperlakukan' were formed gradually. For the word 'memperlakukan', the stages start from the basic word of 'lakukan' (do), 'perlakukan' (treat), and finally 'memperlakukan' (treating). The same thing applies for the word 'memberlakukan' (enacting), the formation stages are 'lakukan' (do), 'berlakukan' (enact), and finally 'memberlakukan' (enacting). Those linguistic forms are formed because of the morphological process that involves simulfixes.

\section{CONCLUSION}

In conclusion, it should be pointed out that this study has succeeded in describing the types of affixes contained in contemporary Indonesian language morphology development. 
Those affixes can be categorized into five, namely prefix, infix, suffix, confix, and simulfix. The study found that in Indonesian language, there are at least eight prefixes, namely 'ber-', 'meN-', 'di-', 'ke-', 'per-', 'peng-', 'se-', 'ter-'. Suffixes can be differentiated into two, which are the regular suffix and the foreign suffix, which can still be classified in more detail into '-an', '-anda', '-i', '-kan', '-wan/wati', '-in', '-at' in one side and the suffixes of '-isasi', '-asi', '-or', '-ee', '-e', '-isme', '-logi', '-tas' on the other side. Infix can be classified into four, namely '-el-', '-em-', '-er-', and '-in-'. The Indonesian language has five types of confix, namely (1) 'ke-an', (2) 'ber-an', (3) 'per-an', (4) 'peng-an', and (5) 'se-nya'. The simulfix in Indonesian language consists of the simulfix (1) 'member-kan' and (2) 'memper-kan'. This study has a limitation in that it has not been able to describe the types of affix that are present contextually in the form of authentic texts. The subsequent study is suggested to base the data which are taken from such texts so that the results of the study can better illustrate the use of affixes in a more actual context.

\section{REFERENCES}

1. N. B. Ratner, "First language acquisition," in International Encyclopedia of Education, 2010.

2. L. Fleming, "Taxonomy and Taboo: The (Meta)Pragmatic Sources of Semantic Abstraction in Avoidance Registers," J. Linguist. Anthropol., 2015.

3. M. Fu, "On Sociopragmatic Equivalence Effect in Translation," US-China Foreign Lang., 2004.

4. R. K. Rahardi, Pragmatik: Kesantunan imperatif bahasa Indonesia. Jakarta: Erlangga, 2009.

5. P. A. Reeder, E. L. Newport, and R. N. Aslin, "From shared contexts to syntactic categories: The role of distributional information in learning linguistic form-classes," Cogn. Psychol., 2013.

6. R. K. Rahardi, Teknik-teknik Pengembangan Paragraf Karya Tulis Ilmiah, 1st ed. Yogyakarta: Universitas Atma Jaya Yogyakarta, 2011.

7. R. K. Rahardi, Bahasa Indonesia untuk Perguruan Tinggi, 1st ed. Jakarta: Erlangga, 2009.

8. Sudaryanto, Metode dan Aneka Teknik Analisis Bahasa, 1st ed. Yogyakarta: Sanata Dharma University Press, 2016.

9. M. Mahsun, "Metode Penelitian Bahasa," Jakarta PT Raja Grafindo Persada, 2005.

10. I. M. Eigsti, L. Bennetto, and M. B. Dadlani, "Beyond pragmatics: Morphosyntactic development in autism," J. Autism Dev. Disord., 2007.

11. D. Farkas and H. de Swart, "The semantics and pragmatics of plurals," Semant. Pragmat., 2010.

12. H. G. Widdowson, "Context, Community, and Authentic Language," TESOL Q., 2006.

13. S. K. Liddell and M. Metzger, "Gesture in sign language discourse," $J$. Pragmat., 1998.

14. D. A. Cruse, "The pragmatics of lexical specificity," J. Linguist., 1977.

15. H. Limberg, "Impoliteness and threat responses," J. Pragmat., 2009.

16. J. Streeck, "Embodied contexts, transcontextuals, and the timing of speech acts," J. Pragmat., 1984.

17. A. Bandura, "Social cognitive theory in cultural context," Applied Psychology. 2002.

18. R. K. Rahardi, Y. Setyaningsih, and R. P. Dewi, "kata fatis penanda ketidaksantunan pragmatik dalam ranah keluarga," Adab. J. Bhs. dan Sastra, 2014

\section{AUTHORS PROFILE}

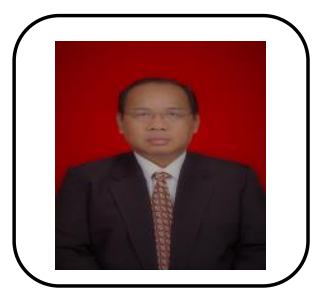

Dr. R. Kunjana Rahardi, M.Hum., was born in Yogyakarta on October 13, 1966. He serves as the Head of Master Program in the Indonesian Language and Literature Education, Faculty of Teachers Training and Education, Sanata Dharma University, Yogyakarta. He graduated from the Doctorate Program of Gadjah Mada University in linguistics in 1999. The linguistic textbooks during his doctorate tenure are: Pragmatik: Kesantunan Imperatif dalam
Bahasa Indonesia (Erlangga Publisher Jakarta, 2006), Asyik Berbahasa Jurnalistik: Kalimat Jurnalistik dan Temali Masalahnya (Santusta Publisher Yogyakarta, 2006), Paragraf Jurnalistik: Menyusun Alinea Bernilai Rasa dalam Bahasa Laras Media (Santusta Publisher Yogyakarta, 2006), Dasar-dasar Bahasa Penyuntingan Media [Gramata Publisher Jakarta, 2009], Penyuntingan Bahasa Indonesia

untuk Karang-mengarang [Erlangga Publisher Jakarta, 2009], Menulis Artikel Opini dan Kolom di Media Massa (Erlangga Publisher Jakarta, 2012), Fonologi dalam Bahasa Indonesia (Universitas Sanata Dharma Press, Yogyakarta, 2014), Sosiopragmatik [Erlangga Publisher Jakarta, 2009 Kajian Sosiolinguistik Kode dan Alih Kode (revised edition) (Ghalia Publisher Indonesia, Jakarta, 2010, 2015), Bahasa Indonesia Perguruan Tinggi: Mata Kuliah Pengembangan Kepribadian (Erlangga Publisher Jakarta, 2010), Bahasa Jurnalistik: Pedoman Kebahasaan untuk Mahasiswa, Jurnalis, dan Umum (Ghalia Publisher Indonesia, Jakarta, 2010; 2015), Pragmatik: Fenomena Ketidaksantunan Berbahasa (Erlangga Publisher Jakarta, 2016), Pragmatik: Fenomena Kefatisan Berbahasa dalam Perspektif Sosio-kultural dan Situasional (Erlangga, Jakarta 2018). He did his thoughts in pragmatics and its interesting sides have been exposed in various nasional and international forums documented in various proceedings and journal articles. He did the research consecutively for five years (in 2013 until 2015 and in 2016 until 2018) on Impoliteness in Indonesian Language and on Phatic Communion in Indonesian Language with the grants given by Directorate of Research and Community Service, Ministry of Research, Technology and Higher Education, Republic of Indonesia.

Published By:

Blue Eyes Intelligence Engineering

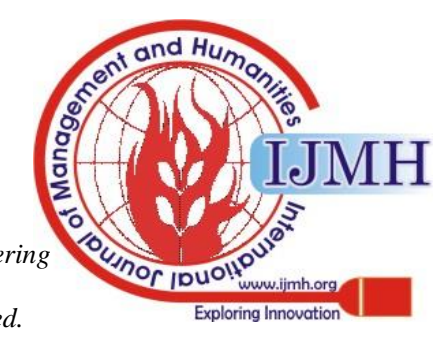

